\title{
CADANGAN KARBON PADA TEGAKAN POHON HUTAN KOTA DI TAMAN MARGASATWA RAGUNAN DKI JAKARTA
}

\author{
Mia Azizah ${ }^{1)}$, Nia Yuliani ${ }^{2)}$, Heriyanto ${ }^{3)}$ \\ ${ }^{1,2,3)}$ Progam Studi Biologi FMIPA Universitas Nusa Bangsa \\ 3)email: miaazizah@unb.ac.id
}

Diterima 19 Februari 2019 disetujui 25 April 2019

\begin{abstract}
Increase environmental problems, such as air pollution and temperatures increase in DKI Jakarta, make the existence of urban forests very important. Trees have an important role because they function as the most efficient carbon sink and storage in urban areas. Along with the increasing number of visitors carrying vehicles, the higher the potential for air pollution in Ragunan Wildlife Park (TMR). The objectives of this study are: To analyze the community structure of tree species that have potential carbon stocks, and estimate carbon stocks stored in tree trunks. The study was conducted in four regions (north, west, east, south) Ragunan Wildlife Park, DKI Jakarta. Vegetation analysis was carried out by calculating the Important Value Index (INP), and carbon stock analysis was carried out through the Allometric approach. The highest INP value was mahoni (Swietinia macrophylla) amounting to 45.51\%, cengal pasir (Hopea odorata) $33.31 \%$, and dao (Dracontomelon dao) $28.26 \%$. The largest amount of carbon reserves is found in the western region, which is $52,503 \mathrm{~kg} / \mathrm{ha}$, and the largest contribution of carbon stocks is from dao trees (Dracontomelon dao) of 30,091 kg / ha, cengal sand 25,372 kg / ha, oil palm (Elaeis guinensis).
\end{abstract}

Keywords: Stored Carbon, Allometrics, Ragunan

\section{PENDAHULUAN}

Hutan merupakan sumber daya alam yang sangat penting dan bermanfaat bagi kehidupan baik secara langsung maupun tidak langsung. Hutan alam merupakan penyimpan karbon (C) tertinggi bila dibandingkan dengan sistem penggunaan lahan (SPL) pertanian, dikarenakan keragaman pohonnya yang tinggi, dengan tumbuhan bawah dan serasah di permukaan tanah yang banyak. Melalui proses fotosintesis, $\mathrm{CO}_{2}$ di udara diserap oleh tanaman diubah menjadi karbohidrat, kemudian disebarkan ke seluruh tubuh tanaman dan akhirnya ditimbun dalam tubuh tanaman berupa daun, batang, ranting, bunga dan buah (Sutaryo, 2009). Kandungan karbon tersimpan dalam lahan dapat dihitung melalui jumlah biomassa yang terdapat pada vegetasi dalam lahan tersebut.
Biomassa hutan berperan penting dalam siklus biogeokimia terutama dalam siklus karbon. Dari keseluruhan karbon hutan, sekitar 50\% diantaranya tersimpan dalam vegetasi hutan (Sutaryo, 2009). Kerusakan hutan, perubahan iklim dan pemanasan global, menyebabkan manfaat tidak langsung dari hutan berkurang, karena hutan merupakan penyerap karbon terbesar dan memiliki peranan yang penting dalam siklus karbon global dan dapat menyimpan karbon sekurang kurangnya 10 kali lebih besar dibandingkan dengan tipe vegetasi lain seperti padang rumput,tanaman semusim dan tundra (Holdgate, 1995). Informasi mengenai cadangan karbon dari berbagai tipe hutan, jenis pohon, jenis tanah dan topografi di Indonesia sangat penting. Menurut data Standar Nasional Indonesia (SNI, 2011) dari seratus empat (104) jenis pohon di Indonesia, baru 11 
jenis pohon yang sudah diketahui cadangan karbonnya. Saat ini sumber data yang komprehensif tentang cadangan karbon di berbagai tipe ekosistem hutan dan penggunaan lahan lain masih terbatas. Hutan kota sebagai salah satu komunitas hutan alam yang terdapat di kota jakarta memiliki peranan yang sangat penting dalam menjaga kelestarian lingkungan kota DKI Jakarta. Hutan kota yg terdapat di Taman Margasatwa Ragunan (TMR) seluas 140 Ha (TMR, 2014). Koleksi tumbuhan berdasarkan inventarisasi pohon pada tahun 2014, di hutan kota TMR terdapat: 92 suku yang meliputi 252 marga, dan 426 jenis. Apabila dibagi menjadi dua kelompok pemanfaatan, setidaknya kekayaan tumbuhan hias tercatat 222 jenis yang termasuk dalam 150 marga dan 51 suku, sedangkan kekayaan tumbuhan peneduh sejumlah 223 jenis yang termasuk 159 marga dan 51 suku, dengan jumlah spesimen keseluruhan 52.733 pohon (TMR, 2014). Keanekaragaman tumbuhan yang tinggi dan belum pernah dilakukan penelitian tentang karbon tersimpan, maka perlu dilakukan penelitian mengenai seberapa besar kandungan karbon tersimpan di Taman Margasatwa Ragunan.
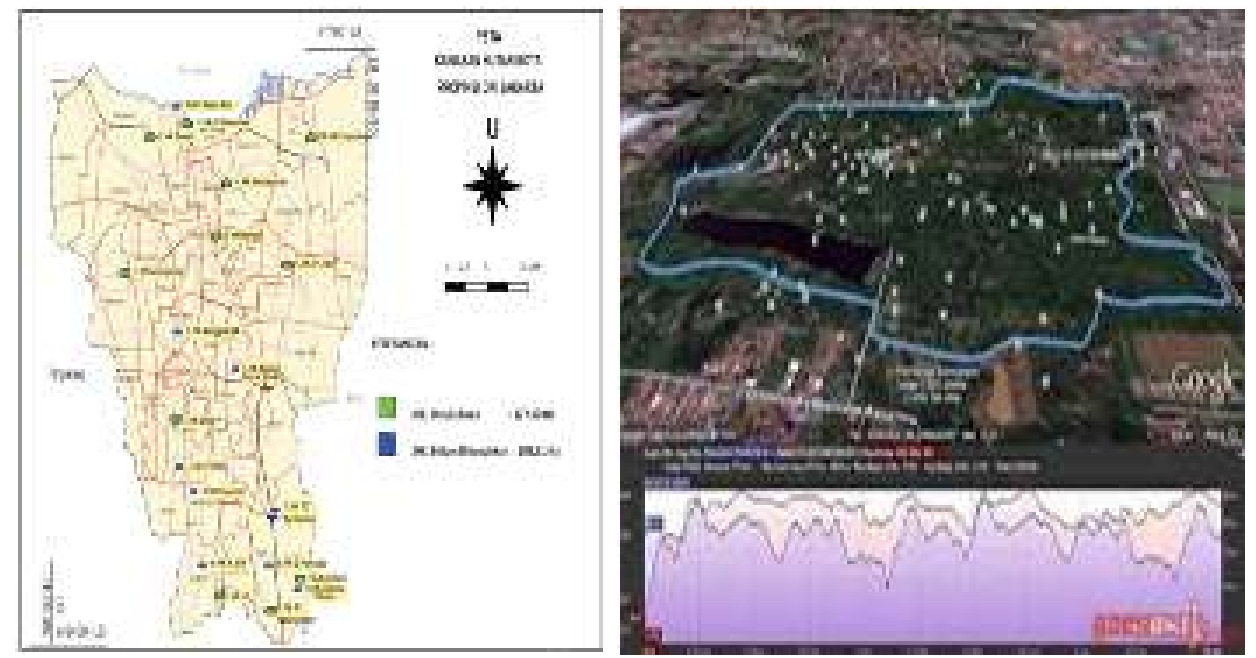

Gambar 1. Peta lokasi hutan kota DKI Jakarta (a), TMR (b) Sumber (source): google maps
Berdasarkan permasalahan yang muncul di DKI Jakarta, maka penelitian ini dilakukan dengan tujuan yaitu: (1) menganalisis struktur komunitas jenis pohon hutan kota yang memiliki cadangan karbon potensial di Taman Margasatwa Ragunan, (2) mengestimasi cadangan karbon tersimpan dalam batang pohon di wilayah Taman Margasatwa Ragunan.

\section{METODE}

Penelitian dilakukan di DKI Jakarta (Gambar 1). Hutan kota yang diamati, yaitu: hutan kota Taman Margasatwa Ragunan (TMR) yang berada di wilayah administarasi Jakarta Selatan dengan luas 140 ha, dengan ketinggian 50 mdpl dan curah hujan 2291 mm per tahun ( BMKG, 2016). Penelitian dilakukan selama dua bulan, yaitu Januari - Februari 2017.

Alat dan bahan yang digunakan dalam penelitian ini yaitu GPS (Global Positioning Sistem), roll meter, pita meteran, tali rafia, alat tulis, kamera, dan kertas label. Bahan yang digunakan yaitu vegetasi hutan kota Taman Margasatwa Ragunan DKI Jakarta. 


\section{Analisis Vegetasi}

Analisis vegetasi dilakukan untuk mengetahui Indeks Nilai Penting (INP), keanekaragaman dan kemerataan jenis tumbuhan pada lokasi atau tempat yang diteliti, untuk analisis vegetasi dilakukan pengambilan sampel dengan menggunakan metode purposive sampling. Sampel lokasi penelitian ditentukan dengan kriteria: tidak memotong badan air (sungai/danau), dan tidak memotong badan jalan, harus cukup luas untuk memuat seluruh jenis yang dimiliki komunitas tumbuhan tersebut, habitatnya harus seragam dalam area tegakan sejauh dapat ditentukan oleh pandangan mata, dianggap mewakili seluruh komunitas tumbuhan di kawasan tersebut (SNI, 2011).

INP tiap jenis pohon diperoleh dengan menghitung parameter penyusun INP yaitu Kerapatan Relatif (KR), Frekuensi Relatif (FR) dan Dominansi Relatif (DR). Kerapatan menyatakan jumlah satu jenis individu dalam plot pengukuran.

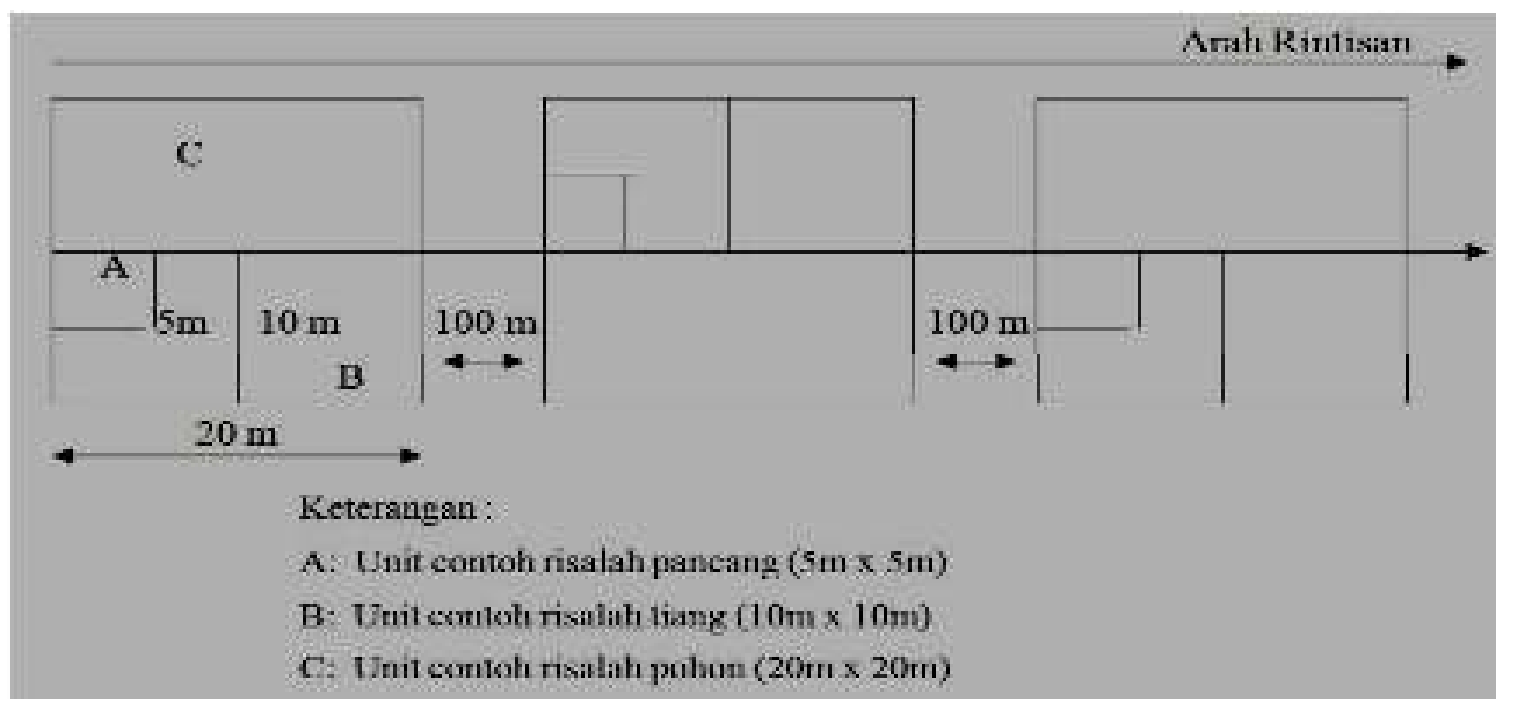

Gambar 2. Desain Metode Garis Berpetak (Kusmana 1997)

Untuk mengetahui komposisi dan struktur komunitas vegetasi menggunakan analisis (Kusmana, 1997) :

Kerapatan (K)

Kerapatan relatif $(\mathrm{KR})$

Frekuensi (F)

Frekuensi relatif(FR)

Dominansi (D)

$$
=\underline{\text { Jumlah Individu (jenis tumbuhan) }}
$$
Luas Petak Contoh (ha)

$$
=\underbrace{\text { Kerapatan total seluruh jenis }}_{\text {Kerapatan suatu jenis }} \text { je0 }
$$

$$
=\frac{\text { Jumlah petak ditemukan suatu jenis }}{\text { Jumlah seluruh petak contoh }}
$$

$=\underline{\text { Frekuensi suatu jenis }} \times 100 \%$ Frekuensi seluruh jenis

$=\underline{\text { Luas bidang dasar suatu jenis }\left(\mathrm{m}^{2}\right)}$ Luas seluruh petak contoh (ha) 
Dominansi relatif $(\mathrm{DR})=\frac{\text { Dominansi suatu jenis }}{\text { Dominansi seluruh jenis }} \times 100 \%$

Indeks Nilai Penting (INP \%) dihitung dengan menggunakan rumus:

$\mathbf{I N P} \%=\mathrm{KR}+\mathrm{FR}+\mathrm{DR}$

Keterangan :

- Komposisi jenis dihitung berdasarkan jumlah jenis tumbuhan yang ditemukan.

- Struktur vegetasi diukur berdasarkan tinggi tegakan vegetasi

Analisis Biomassa

Penentuan biomassa pohon hutan kota dilakukan dengan metode sampling tanpa pemanenan (nondestruktive sampling), yaitu menggunakan persamaan allometrik berdasarkan spesies tanaman (Kusmana, 1997). Persamaan allometrik merupakan suatu fungsi atau persamaan matematika, yang menunjukkan hubungan antara bagian tertentu dari mahluk hidup dengan bagian lain atau fungsi tertentu dari makhluk hidup tersebut. Persamaan ini digunakan untuk menduga parameter tertentu dengan menggunakan parameter lainnya yang lebih mudah diukur yaitu diameter dan tinggi (Hairiah et al. 2011). Persamaan allometrik memiliki kelebihan yaitu tidak melakukan penebangan atau perusakan terhadap pohon, lebih efesien terhadap waktu dan biaya. Metode ini juga sesuai dengan pasal 26 ayat 2 PP No. 63 Tahun 2003 tentang larangan melakukan perusakan terhadap pohon hutan kota.

Formulasi umum yang digunakan dalam pendugaan biomassa adalah sebagai berikut:

$$
\mathbf{Y}=\mathbf{a} . \mathbf{D B H} \mathbf{H}^{\mathbf{b}}
$$

Keterangan:

$\mathrm{Y} \quad$ : biomassa atas permukaan $(\mathrm{kg})$

DBH : Diameter setinggi dada $(1,3$

meter)

a : Koefisien Konversi

b : Koefisien allometrik.

Tabel 1 Persamaan Alometrik

\begin{tabular}{|c|c|c|}
\hline Jenis pohon & Persamaan allometrik & Sumber \\
\hline Jati & $\mathrm{Y}=0.153 \mathrm{D}^{2,39}$ & Hairiah et al., (2011) \\
\hline Mahoni & $\mathrm{Y}=0.048 \mathrm{D}^{2,68}$ & Hairiah et al., (2011) \\
\hline Sengon & $\mathrm{Y}=0.027 \mathrm{D}^{2,23}$ & Hairiah et al., (2011) \\
\hline Akasia & $\mathrm{Y}=0.0000478 \mathrm{D}^{2,76}$ & Hairiah et al., (2011) \\
\hline Karet & $\mathrm{Y}=419-16.9 \mathrm{D}+0.322 \mathrm{D}^{2}$ & Hairiah et al., (2011) \\
\hline Puspa & $\mathrm{Y}=0.000093 \mathrm{D}^{2,51}$ & Krisnawati et al., (2012) \\
\hline Pohon lain * & $\mathrm{Y}=0.112\left(\pi \mathrm{D}^{2} \mathrm{H}\right)^{0,92}$ & Chave at al., (2005) \\
\hline Pohon lain $* *$ & $\mathrm{Y}=0.051 \times \pi \mathrm{D}^{2} \mathrm{H}$ & Chave at al., (2005) \\
\hline Pohon lain $* * *$ & $\mathrm{Y}=0.0776 \times\left(\pi \mathrm{D}^{2} \mathrm{H}\right)^{0,94}$ & Chave at al., (2005) \\
\hline
\end{tabular}

\footnotetext{
Keterangan:

$\mathrm{Y} \quad=$ Biomassa pohon $(\mathrm{kg}$ per pohon)

$\mathrm{D} \quad=\mathrm{DBH}(\mathrm{cm})$

$\mathrm{H} \quad=$ Tinggi pohon $(\mathrm{m})$
} 
$\pi \quad=$ BJ kayu $(\mathrm{g}$ per $\mathrm{cm})$

* Persamaan allometrik dengan curah hujan $<1.500 \mathrm{~mm}$ (kering)

** Persamaan allometrik dengan curah hujan 1.500 - $4.000 \mathrm{~mm}$ (lembab)

*** Persamaan allometrik dengan curah hujan $>4.000 \mathrm{~mm}$ (basah)

\section{Analisis cadangan karbon}

Analisis cadangan karbon pohon hutan kota menggunakan pendekatan kandungan biomassa yang dikembangkan oleh IPCC (2011).
Biomasa batang pohon diukur untuk seluruh jenis pohon yang terdapat pada plot pengamatan. Formulasi umum yang digunakan adalah:

$$
\mathrm{C}=0.5 \times \mathrm{W}
$$

Keterangan:

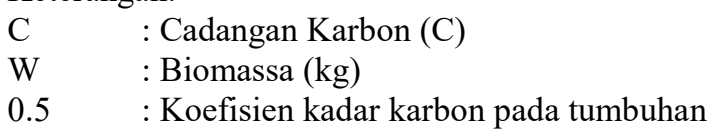

\section{HASIL DAN PEMBAHASAN Analisis Vegetasi}

Hasil analisis vegetasi di TMR menunjukkan jenis pohon dengan nilai $\mathrm{KR}$ tertinggi terdapat pada jenis Mahoni (Swietinia macrophylla) dengan nilai sebesar $22,22 \%$, tingginya nilai tersebut menunjukkan bahwa mahoni merupakan pohon dengan tingkat kerapatan tertinggi di TMR. Jenis pohon yang sering muncul adalah growak (Grewia acuminata) dengan nilai FR 9,09 \%, sedangkan untuk nilai DR tertinggi terdapat pada pohon cengal pasir (Hopea odorata) yaitu sebesar 19,77 \% ini berarti bahwa cengal pasir merupakan jenis pohon yang mendominasi dengan luas basal area paling tinggi. Untuk jenis pohon dengan INP tertinggi masing-masing adalah mahoni (Swietinia macrophylla) sebesar 45,51 \%, cengal pasir (Hopea odorata) 33,31 \%, dan pohon kaya/Dao (Dracntomelon dao) 28,26 $\%$. Hal ini menunjukkan bahwa mahoni, Cengal pasir, dan Dao merupakan jenis tumbuhan yang paling banyak menyusun komunitas vegetasi di lokasi penelitian.

Indeks Nilai Penting (INP) menyatakan peran suatu tumbuhan di dalam komunitas. Makin besar INP suatu jenis tumbuhan, maka makin besar pula peranan jenis tersebut di dalam komunitas yang diukur. Jika INP merata pada banyak jenis, dapat dikatakan keanekaragaman hayati di komunitas tersebut semakin tinggi (Rahayu, 2007). Berdasarkan hasil penelitian, jumlah sampling data pohon yang diambil dari empat titik wilayah di TMR (utara, barat, timur, dan selatan) seluruhnya berjumlah 301 pohon, yang terbagi dalam 27 jenis dalam 17 plot pengukuran (Lampiran 2). Di titik utara terdapat 9 jenis spesies dengan jumlah 108 pohon, titik barat 12 jenis spesies dengan jumlah 69 pohon, titik timur terdapat 8 jenis spesies dengan jumlah 82 pohon, dan titik selatan terdapat 8 jenis spesies dengan jumlah 42 pohon. Nilai Frekuensi Relatif (FR), Kerapatan Relatif (KR), 
Dominansi Relatif (DR) dan INP masing-masing jenis pohon terdapat Tabel 2.

Berdasarkan hasil analisis data, hasil INP tertinggi adalah pohon mahoni (Swietenia macrophylla) yang merupakan anggota suku Meliaceae, Mahoni termasuk pohon besar dengan tinggi pohon mencapai 35-40 $\mathrm{m}$ dan diameter mencapai 125 $\mathrm{cm}$. Pohon mahoni bisa mengurangi polusi udara sekitar $47 \%-69 \%$ sehingga disebut sebagai pohon pelindung sekaligus filter udara dan daerah tangkapan air. Daun-daun Mahoni dapat menyerap polutanpolutan di sekitarnya. Sebaliknya, dedaunan itu akan melepaskan oksigen $\left(\mathrm{O}_{2}\right)$ yang membuat udara di sekitarnya menjadi segar (Warino, 2016). Ketika hujan turun, tanah dan akar-akar pepohonan itu akan mengikat air yang jatuh, sehingga menjadi cadangan air Mahoni dapat tumbuh dengan subur di pasir payau dekat dengan pantai dan menyukai tempat yang cukup sinar matahari langsung. Tanaman ini termasuk jenis tanaman yang mampu bertahan hidup di tanah gersang sekalipun. Kemampuan tumbuh yang sanggup hidup di berbagai tipe lahan tanam, maka tidak heran jika pohon mahoni dapat tumbuh dan berkembang dengan baik di Taman Margasatwa Ragunan, serta menempati urutan pertama dengan Indeks Nilai Penting (INP).

\footnotetext{
Pohon cengal pasir (Hopea odorata) merupakan famili Dipterocarpacea pohon ini berasal dari Asia Tenggara, menyebar mulai India (Pulau Andaman), Myanmar, Thailand dan Indocina dan ke selatan sampai semenanjung Malaysia utara. Pada kebanyakan sebaran alaminya,
}

jenis ini tumbuh di hutan tropis dataran rendah dengan tanah subur sampai ketinggian $300 \mathrm{~m}$ dpl, lokasi tumbuhnya tidak jauh dari sungai. Namun, populasi di India tumbuh di hutan basah selalu hijau pada ketinggian, jauh dari sungai. Pertumbuhan terbaik pada daerah bercurah hujan tahunan lebih 1.200 $\mathrm{mm}$ dan suhu rata-rata $25-27^{\circ} \mathrm{C}$. Dapat tumbuh pada habitat yang beragam serta mudah dibudidayakan. Keberadaannya di TMR sebagai tanaman yang sengaja ditanam oleh pihak pengelola, sehingga saat ini selain sebagai resapan air pohon cengal pasir juga berfungsi sebagai taman peneduh bagi pengunjung TMR. Taman ini merupakan rangkaian taman kandang peragaan satwa dan ruang terbuka hijau yang ditutupi oleh kerimbunan pohon cengal pasir (Hopea odorata) (TMR, 2014). Pihak pengelola dan karyawan TMR sendiri menyebut taman ini sebagai taman kemenyan, ini dimungkinkan karena apabila kayu pohon ini dibakar akan mengeluarkan bau seperti bau kemenyan.

$$
\text { Pohon buah dao/rao }
$$

(Dracontomelon dao) termasuk dalam famili Anacardiaceace. Selain itu jenis ini juga dikenal dengan nama dahu, sengkuang (Kalimantan), dan basuong (Papua). Pohon jenis ini tersebar pada hutan dataran rendah di pulau Seram, namun ketinggian 500$1000 \mathrm{~m}$ sudah jarang ditemukan. Jenis pohon ini dapat tumbuh pada drainase tanah yang baik sampai yang buruk, terutama pada tanah rawa. Perbanyakan tanaman ini biasanya menggunakan biji. Di dalam $1 \mathrm{~kg}$ terdapat $520-620$ biji atau 70 buah segar. Dracontomelon dao mencapai tinggi 3-4 meter setelah 2 tahun dan 
6,5 meter setelah 5,5 tahun. Di lapangan tinggi mencapai 55 meter dengan batang bebas cabang setinggi 25 meter dan diameter mencapai 150 meter (Irwanto, 2009). Taman pohon dao terdapat tepat di depan masjid dan kandang mamalia kecil, merupakan pohon yang sengaja ditanam oleh pihak pengelola.

\section{Analisis Cadangan Biomassa dan Karbon pohon}

Hasil cadangan karbon dan biomassa pohon di Taman Margasatwa Ragunan pada masing-masing titik dapat dilihat pada Tabel 1.

Tabel 1.Total cadangan karbon dan biomassa ditiap stasiun/titik

\begin{tabular}{ccc}
\hline TITIK & $\begin{array}{c}\text { BIOMASSA } \\
\text { (kg/ha) }\end{array}$ & $\begin{array}{c}\text { KARBON } \\
\text { (kg/ha) }\end{array}$ \\
\hline Barat & 105.006 & 52.503 \\
Utara & 81.885 & 40.943 \\
Timur & 35.997 & 17.999 \\
Selatan & 31.255 & 15.628 \\
\hline Jumlah & 254.143 & 127.073 \\
\hline
\end{tabular}

Berdasarkan hasil analisis cadangan karbon tersimpan di Taman Marga satwa Ragunan (TMR) DKI Jakarta, maka diperoleh total cadangan karbon pohon sebesar $127.073 \mathrm{~kg} / \mathrm{ha}$. Jumlah cadangan karbon pohon terbesar terdapat pada titik barat dengan jumlah karbon $52.503 \mathrm{~kg} / \mathrm{ha}$. Nilai cadangan karbon pohon ini menunjukkan bahwa lanskap hutan kota selain memiliki fungsi sebagai konservasi keanekaragaman hayati, hidrologi dan estetika juga memiliki andil dan fungsi sebagai penyimpan karbon.

Wilayah barat mempunyai nilai simpanan karbon tertinggi dikarenakan kerapatan antar pohon di wilayah ini sangat tinggi. Hal ini sesuai dengan Rahayu et al (2007) yang mengatakan bahwa selain diameter batang, kerapatan pohon juga mempengaruhi peningkatan cadangan karbon melalui peningkatan biomassa. Wilayah barat juga dikenal dengan adanya taman hutan wisata, pada wilayah barat ini pola pengelolaan taman yang diterapkan cenderung berbeda dengan taman lainnya, ditunjukkan dengan ditemukannya jenis-jenis tumbuhan ikutan yang berkembang secara alami. Selain jenis tumbuhan utama yang sengaja ditanam pihak pengelolah, di wilayah barat ini juga tumbuh jenis ikutan yang berkembang secara alami melalui pemecahan biji secara sendiri atau melalui bantuan satwa dan air diantaranya adalah growak (Grewia acuminata), karet (Haavea brasiliensis), awar-awar (Ficus septica). Wilayah selatan merupakan penyumbang karbon terendah dibandingkan wilayah lain, ini dikarenakan sebagaian besar wilayah selatan merupakan hamparan rumput dan kerimbunan liana yang cenderung menekan awal pertumbuhan tanaman utama trembesi (Samanea saman). Selain itu di wilayah ini juga terdapat 3 buah danau yang letaknya saling bersebelahan sehingga makin mempersempit lahan tumbuh dan 
berkembangnya jenis pohon-pohon di wilayah selatan (TMR, 2014).

Cadangan karbon pohon mengalami peningkatan seiring dengan peningkatan diameter batang. Hal ini sesuai dengan Kusmana (1992) dan Rayahu (2007) yang mengatakan bahwa salah satu faktor penting yang menentukan besarnya suatu cadangan karbon pohon adalah diameter batang pohon. Dijelaskan pula bahwa cadangan karbon pada komunitas hutan salah satunya dipengaruhi oleh diameter batang. Pohon dao (Dracntomelon dao) memiliki jumlah karbon tertinggi dikarenakan memiliki jumlah pohon dan diameter batang yang cukup besar, rataan diameter pohon dao yang diukur di TMR berkisar antara 21-96,8 cm. Kayu buah Dao termasuk kayu perdagangan, buah nya juga dapat di makan dengan rasa yg manis bila sudah matang. Pemanfaatan lokal di Papua, daun dan bunga dimakan sebagai sayur. Sedangkan di Maluku digunakan sebagai penyedap rasa. Kulit batang dapat dijadikan obat tradisional untuk menyembuhkan disentri. Dracntomelon dao selain sebagai pohon peneduh, dan penyimpaan karbon, kayu nya juga dapat memberikan penghasilan tambahan bagi masyarakat bila dikelola dengan baik (Irwanto, 2009).

\section{SIMPULAN}

Jenis pohon dengan INP tertinggi sebesar 45,51 \% adalah Swietenia macrophylla. Jumlah total cadangan karbon pohon di TMR sebesar 127.073 $\mathrm{kg} / \mathrm{ha}$, serta jenis pohon dengan rata-rata karbon terbesar adalah Dao (Dracontomelon dao) sebesar 30.091 $\mathrm{kg} / \mathrm{ha}$.

\section{DAFTAR PUSTAKA}

Arief, A. 2001. Hutan dan Kehutanan. Penerbit Kanisius. Yogyakarta.
Badan Penelitian dan Pengembangan Kehutanan.2010. Pedoman Pengukuran Karbon untuk mendukung Penerapan REDD + di Indonesia. Bogor: Pusat Penelitian dan Pengembangan Perubahan Iklim dan Kebijakan.

Badan Standardisasi Nasional. 2011.Pengukuran dan penghitungan cadangan karbon Pengukuran lapangan untuk penaksiran cadangan karbon hutan (groundbased forest carbon accounting) Nomor 7724. Jakarta.

Dahlan, I.N. S. Jaya dan Istomo. 2005. Estimasi Karbon Tegakan Acacia mangium Willd Menggunakan Citra Landsat ETM+ dan SPOT-5: Studi Kasus di BKPH Parung Panjang KPH Bogor.

Departemen Kehutanan. 1999. UndangUndang Republik Indonesia No 41 Tahun 1999 Tentang Kehutanan. Jakarta

Greig-Smith, P., 1983. Quatitative Plant Ecology. Oxford: Blackwell Scientitific Publication

Hairiah K. Rahayu S. 2007. Pengukuran 'karbon tersimpan' di berbagai macam penggunaan lahan. Bogor. World Agroforestry Centre ICRAF, SEA Regional Office, University of Brawijaya, Unibraw, Indonesia. $77 \mathrm{p}$.

IPCC. 2011. IPCC Guidelines for National Greenhouse Gas Inventories, Prepared by the National Greenhouse Gas Inventories Programme, Eggleston H.S., Buendia L, Miwa K., Ngara T. and Tanabe K. (eds). Published: IGES, Japan. Kehutanan. Institut Pertanian Bogor. Bogor.

Kusmana, C. 1997. Metode Survey Vegetasi. Bogor: Penerbit Institut Pertanian Bogor

Pambudi, G. Prastya. 2011. Pendugaan Biomassa Beberapa Kelas Umur 
Tanaman Jenis Rhizophora apiculata bl. Pada Areal pt. Bina Ovivipari Semesta Kabupaten Kubu Raya, Kalimantan Barat. Departemen Konservasi Sumberdaya Hutan Dan Ekowisata Fakultas Kehutanan Institut Pertanian Bogor.

Solichin, M. 2011. Tekhnik Pendugaan Cadangan Karbon Hutan: German International Cooperation. Merang REDD Pilot Project. Hal: 4-6. Matter Dinamics and Greenhouses Emission After Forest Conversion. Report of Workshop Training Course. Bogor. Indonesia.

Solikhin. 2009. Panduan Inventarisasi Karbon di Ekosistem Hutan Rawa Gambut Studi Kasus di Hutan Rawa Gambut Merang, Sumatera Selatan. Merang REDD Pilot Project South Sumatera-GIZ, Palembang

Standar Nasional Indonesia (SNI), 2011.Pengukuran dan Perhitungan Cadangan Karbon.Badan Standarisasi Nasional.Jakarta.
Subarudi, I. Somsoedin, dan T. Waryono. 2010. Kebijakan Pembangunan RTH dan Hutan Kota di Wilayah Jabodetabek: Sebuah Upaya Pencegahan Tenggelamnya Kota Jakarta. Prosiding Ekspose Hasil Penelitian Pusat Penelitian Sosial ekonomi dan Kebijakan Kehutanan, Tanggal 30 September 2010. Pusat Penelitian, Pengembangan Perubahan Iklim dan Kebijakan, Kementrian Kehutanan. Bogor.

Suhendang E. 2002. Pengantar Ilmu Kehutanan. Yayasan Penerbit Fakultas.

Sutaryo, Dudun. 2009. Perhitungan Biomassa (Sebuah Pengantar untuk Studi Karbon dan Perdagangan

Karbon). Dipublikasikan pada Mei 2009 oleh Wetlands International Indonesia Programme: Bogor.

TMR. 2014. Invtarisasi pohon di TMR. Laporan teknis. PT. airmas intercontinental. 